\title{
NOVEL MORTAR CONTAINING WASTE GLASS AND CLAY BRICK POWDER FOR SUSTAINABLE CONSTRUCTION
}

\author{
OLUWAROTIMI OLOFINNADE ${ }^{1}$, CYNTHIA CHIGERE ${ }^{1}$, DAVID NDUKA ${ }^{2}$, OPEYEMI \\ JOSHUA $^{2}$, and BABATUNDE OGUNBAYO ${ }^{2}$ \\ ${ }^{1}$ Dept of Civil Engineering, Covenant University, Ota, Nigeria \\ ${ }^{2}$ Dept of Building Technology, Covenant University, Ota, Nigeria
}

\begin{abstract}
Due to the increasing need for sustainability, the need for a cleaner environment and resources conservation has now become very important. This study investigates the possible utilization of waste glass powder combined with pulverized fired clay brick wastes as a partial replacement for Portland cement in the production of mortar. The fired clay bricks and glasses were sourced as waste materials and then crushed into powder form. It is then combined and used to partially substitute Portland cement in the mortar at replacement levels of $0,5,10,20,25,30,40$ and $50 \%$ using a mix ratio of $1: 2.75$ at 0.5 water-binder ratios. Physical, chemical and morphological characterization was carried out on the pulverized materials. Further, the compressive strength test was carried out on casted $100 \mathrm{~mm}$ cube samples after curing by immersion in water. Obtained results revealed the pozzolanic reactivity potential of the blended waste glass and fired clay brick powder due to their amorphousness and high silica content, while also exhibiting similar oxides compositions. Moreover, the obtained compressive strength results of the blended mortar depict improved strength especially at an optimum value of $15 \%$ cement substitute with the blended fired clay brick and glass powder compare to the control. It is therefore suggested that blended mix of waste glass and fired clay brick powder with cement can be used in mortar component instead of open disposal in a landfill.
\end{abstract}

Keywords: Modified mortar, Pozzolanic materials, Building materials, Compressive strength, Waste recycling, Sustainability.

\section{INTRODUCTION}

In recent times, sustainability has become one of the dominant issues in the world. Report by Bacun (2003) affirmed that sustainability is an approach and attitude that advocated that all economic activities should be more concern about the ecosystem. Such economic activities in the construction industry for instance was reported to be characterized with large consumption of nonrenewable resources and energy leading to resource depletion and emission of enormous amount of greenhouse gases into the atmosphere (Bilodeau and Malhotra 2000, Calkin 2009, Kline and Barcelo 2012, Olofinnade et al. 2017a, Olofinnade et al. 2019). Hence, it is important that the construction industry to embrace sustainability as a mean of achieving sustainable construction (Mehta 2001, Olofinnade et al. 2019). Among the fundamentals of sustainability as relates to the construction industry are utilizing minimal natural resources, less energy 
consumption, and also finding alternative means to reduce, reuse and recycle waste materials that may be harmful to the environment (Akinwumi et al. 2016, Olofinnade et al. 2018b).

Recycling and reusing of waste materials is one of the key alternatives the industry can adopt to achieve such sustainable construction thereby limiting or reducing the use of raw nonrenewable resources or disposal of the wastes to a possible minimal level (Olofinnade et al. 2019, Ngene et al. 2019). This strategy further highlights the possibility of using nonrenewable resources and energy in such a manner without compromising the future (Calkins 2009, Provis and van Deventer 2014). A report by Mehta and Monteiro (2006) mentioned that yearly, concrete and mortar production, which are the most traditionally used building materials required over 1.5 billion tonnes of cement. These huge amounts indicate an enormous amount of raw materials depletion, energy consumption and carbon dioxide $(\mathrm{CO} 2)$ emission into the air from the activities of cement production.

Many previous studies have reported on the impact of greenhouse gases emission on the environment (Moya et al. 2010, Shakir et al. 2014, Olofinnade et al. 2019). In addition, studies have also shown that the environmental footprints of cement can be mitigated through the use of supplementary cementitious materials mostly sourced as waste or by-product from the industries such as fly ash, silica fume, rice husk ash and slag utilized as replacement material to partially substitute cement in production of concrete and mortar (Schneider et al. 2011, Meyer 2013). However, with the persistent improvement of knowledge, solid waste materials such as glass and clay brick are being considered as alternative materials for cement replacement.

Various studies have also investigated the use of glass and clay brick wastes as a replacement for aggregates in concrete and mortar (Ismail and Al-Hashmi 2009, Tan and Du 2013, Aliabdo et al. 2014, Olofinnade et al. 2017a). However, a major limitation on the use of crushed glass as natural aggregates replacement is the possible swelling and cracking of the concrete and mortar due to the expansive reaction between the cement alkalis and reactive silica (Du and Tan 2014). In contrast, studies have also shown the huge potential of using waste glass in finely grounded form as a partial replacement material for cement. It was reported that finely ground waste glass possesses the required pozzolanic activity and enhances the specific properties of cement paste, mortar and concrete (Shao et al. 2000, Shayan and Xu 2004, Olofinnade et al. 2017b, Kong et al. 2018). Similarly, clay brick calcined at a high temperature of about $900^{\circ} \mathrm{C}$ contains applicable oxide constituents which classified it as pozzolana (Bektas et al. 2008, Olofinnade et al. 2018a).

Thus, implying that finely ground waste clay brick can be possibly deployed as a pozzolan to partially substitute cement in cement paste, mortar and concrete (Olofinnade et al. 2016, Olofinnade et al. 2018a). However, this current study is aimed at investigating the strength development of mortar mixture containing blends of finely ground waste glass powder and fired clay brick powder used as cement replacement in the production of sustainable mortar for construction.

\section{MATERIALS AND METHODS}

In this study, the materials used include; Portland cement of grade 42.5 conforming to NIS 444 (2003) with a specific gravity of 3.15 . The fine aggregate is river sand $(0.075 \mathrm{~mm}-4.75 \mathrm{~mm})$ with a specific gravity of 2.62. The glass was obtained as discarded bottles and containers from waste collection locations within Ota town, Nigeria. Before the glass wastes were finely ground, the discarded bottles and containers were properly cleaned with water and air-dried openly to remove any forms of impurities. The clay brick wastes sourced as demolished wastes from a demolishing building site within Ota town, Ogun State, Nigeria, were thoroughly sorted to remove unwanted debris, dirt and metals, and then crushed into powdery form. The mixing water 
is from the structures and material laboratory. The oxides compositions of the finely ground waste glass powder, waste clay brick powder and cement obtained was determined using the $\mathrm{x}$ ray fluorescence (XRF) as shown in Table 1, while Table 2 shows the mix proportioning for the mortar constituents used at a mix proportion of 1:2.75 (binder: sand) at a constant water/binder ratio of 0.5 . The pulverized waste glass and fired clay brick powder was properly blended and used to partially substitute cement in the mortar at replacement levels of $0,5,10,20,25,30,40$ and $50 \%$ using the above-mentioned mix ratio. The morphology of the finely ground waste glass and fired clay brick powder and cement particles were determined using the scanning electron microscopy (SEM), equipped with the energy dispersion spectroscopy (EDS).

The results of the SEM micrographs are presented in Figure 1 $(\mathrm{a}-\mathrm{c})$. Mortar samples were produced using cubes of $100 \mathrm{~mm}$ dimensions, and batching was carried out by weighing. All samples were removed from the mold after $24 \mathrm{hrs}$ and cured in water for 28 days. Strength properties of the hardened control mortar samples and those containing blended waste glass and fired clay brick powder at different replacement levels for cement were carried out following the requirement of ASTM C109 (2005).
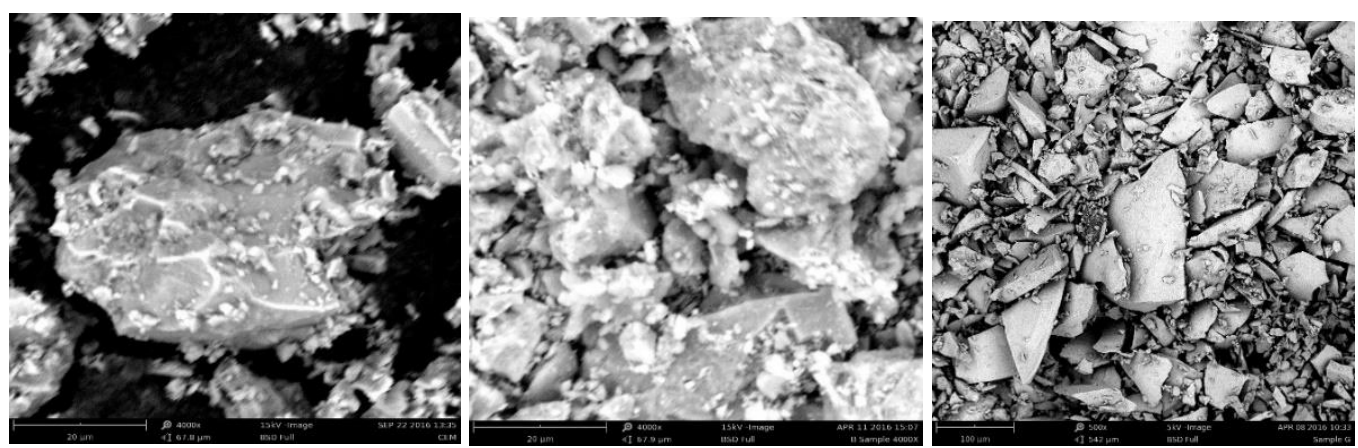

Figure 1. (a) Micrographs of cement particles; (b) fired clay brick powder particles; (c) waste glass powder particles.

Table 1. Chemical composition of binder materials.

\begin{tabular}{rccccccccc}
\hline Composition, \% & $\mathrm{SiO}_{2}$ & $\mathrm{Al}_{2} \mathrm{O}_{3}$ & $\mathrm{Fe}_{2} \mathrm{O}_{3}$ & ${ }^{\mathrm{CaO}}$ & ${ }_{\mathrm{MgO}}$ & $\mathrm{K}_{2} \mathrm{O}$ & $\mathrm{Na}_{2} \mathrm{O}$ & $\mathrm{TiO}_{2}$ & $\mathrm{P}_{2} \mathrm{O}_{5}$ \\
\hline Cement & 24.08 & 19.40 & 6.28 & 74.25 & 3.96 & 0.85 & 1.74 & 0.62 & 1.21 \\
Clay brick & 60.64 & 14.23 & 4.93 & 0.27 & 1.72 & 1.44 & 1.94 & 0.98 & 0.90 \\
Waste glass & 64.30 & 19.98 & 6.30 & 10.60 & 0.63 & 0.74 & 12.52 & 0.61 & \\
\hline
\end{tabular}

Table 2. Mix proportion of the mortar constituents.

\begin{tabular}{llllllllll}
\hline \multicolumn{1}{c}{ Materials } & $\mathbf{0}$ & $\mathbf{5 \%}$ & $\mathbf{1 0 \%}$ & $\mathbf{1 5 \%}$ & $\mathbf{2 0 \%}$ & $\mathbf{2 5 \%}$ & $\mathbf{3 0 \%}$ & $\mathbf{4 0 \%}$ & $\mathbf{5 0 \%}$ \\
\hline Sand (kg) & 11 & 11 & 11 & 11 & 11 & 11 & 11 & 11 & 11 \\
Water (kg) & 1.8 & 1.8 & 1.8 & 1.8 & 1.8 & 1.8 & 1.8 & 1.8 & 1.8 \\
Cement (kg) & 4 & 3.8 & 3.6 & 3.4 & 3.2 & 3.0 & 2.8 & 2.4 & 2.0 \\
Clay brick powder (kg) & - & 0.1 & 0.2 & 0.3 & 0.4 & 0.5 & 0.6 & 0.8 & 1.0 \\
Waste glass powder (kg) & - & 0.1 & 0.2 & 0.3 & 0.4 & 0.5 & 0.6 & 0.8 & 1.0 \\
\hline
\end{tabular}




\section{RESULTS AND DISCUSSION}

The SEM micrographs showing the morphology of the finely ground waste glass powder, clay brick powder and cement particles are presented in Figures 1(a-c) respectively. The EDS microanalysis carried out identified the predominant elements in both the waste glass and fired clay brick powder materials to be silicon $(\mathrm{S})$ and oxygen $\left(\mathrm{O}_{2}\right)$, while in the cement the dominant elements are calcium $(\mathrm{Ca})$ and oxygen $\left(\mathrm{O}_{2}\right)$. The obtained results agreed with the chemical compositions results of the XRF analysis conducted on the materials shown in Table 1. The results show the dominant oxide in the glass and clay brick powder materials is Silica $\left(\mathrm{SiO}_{2}\right)$, thus implying that both materials contains high silica contents in sufficient percentage, including relevant chemical compositions that are used to classified pozzolanic materials that can be used for partial replacement of cement according to the ASTM C618 (2012) specification as also reported in the studies of Olofinnade et al. $(2016,2017 \mathrm{~b})$. Meanwhile, Calcium oxide (CaO) was observed to be dominant.in the cement.

Figure 2 depicts the compressive strength development through the 28 days curing of the mortar samples. The results indicate that the tested mortar samples show an increasing trend in strength as the age of curing increases for the control and modified mortar samples. Meanwhile, while the control sample demonstrated higher strength development relative to other tested samples, it was observed that modified mortar samples containing 5\% and $10 \%$ blended finely ground glass and clay brick powder show strength that is comparable to the control after 28 days of curing. However, a modified mortar sample containing 15\% blended fired clay brick and glass powder as cement replacement achieve a much higher strength of about $18 \%$ gain compared to the control after 28 days of curing. The strength gain could be attributed to the pozzolanic effect of the blended clay brick and glass powder together with cement. It may also be attributed to an improve pore structure of the hardened mortar resulting in a much denser mortar thereby causing an improved compressive strength of the mortar. Besides, no appreciable increase in strength was noticed beyond the $15 \%$ cement replacement as a result of the retarding influence of the blended clay brick and glass powder on hydration. But it is possible the influence might be further improved upon by subjecting the mortar samples containing blended materials beyond $15 \%$ to an extended duration of curing, especially samples containing $20 \%$ blended fired clay brick and glass powder.

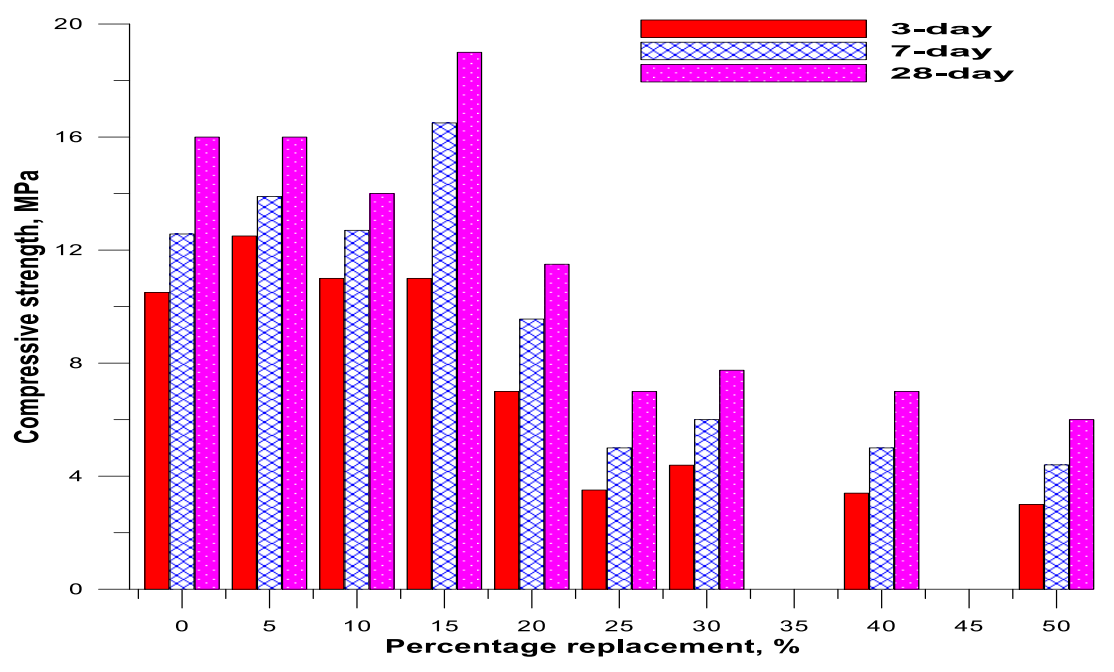

Figure 2. Compressive strength development with blended content. 


\section{CONCLUSION}

In this study, the materials considered were shown to contain high silica content and relevant oxides constituent for pozzolanic materials. Moreso, the mortar mixes exhibited an increase in compressive strength as the curing age increases. In addition, while the control mortar shows high strength properties, mortar samples containing 5\%,10\% and $15 \%$ blended clay brick and glass powder showed an improve compressive strength compare to the control mortar. Consequently, based on the findings, it is suggested that blended finely ground waste glass and clay brick powder at optimum 15\% replacement level for cement can be deployed in cement mortar for sustainable construction.

\section{Acknowledgments}

We wish to appreciate the Management of Covenant University for their financial support.

\section{References}

Akinwumi, I. I., Awoyera, P. O., Olofinnade, O. M., Busari, A. A., and Okotie, M., Rice Husk as A Concrete Constituent: Workability, Water Absorption and Strength of the Concrete, Asian Journal of Civil Engineering, 17, 887-898, 2016.

Aliabdo, A. A., Abd-Elmoaty, A. M., and Hassan, H. H., Utilization of Crushed Clay Brick in Concrete Industry, Alexandria Engineering Journal, 53(1), 151-168, March, 2014.

ASTM C109, Standard Test Method for Compressive Strength of Hydraulic Cement Mortars (Using 100 Mm Cube Specimens), ASTM International, West Conshohocken, PA, 2005.

ASTM C618-12a, Standard Test Methods for Coal Fly Ash and Raw or Calcined Natural Pozzolan for Use in Concrete, ASTM International, West Conshohocken, PA, 2012.

Bačun, D., E-Održivost, Globalna Inicijativa, ISO Forum Croaticum, 2003.

Bektas, F., Wang, K., and Ceylan, H., Use of Ground Clay Bricks as A Pozzolanic Materials in Concrete, Journal of ASTM International, 5, ISSN 1546-962X, 2008.

Bilodeau, A., and Malhotra, V. M., High Volume Fly Ash System: Concrete Solution for Sustainable Development, ACI Materials Journal, 1, 41-47, January, 2000.

Calkins, M., Materials for Sustainable Sites: A Complete Guide to the Evaluation, Selection, and Use of Sustainable Construction Materials, Wiley, Hoboken, NJ, 2009.

Du, H., and Tan, K. H., Effect of Particle Size On Alkali-Silica Reaction in Recycled Glass Mortars, Construction and Build. Materilas, 66, 275-285, https://doi.org/10.1016/j.conbuildmat.2014.05.092, 2014.

Ismail, Z. Z., and Al-Hashmi, E. A., Recycling of Waste Glass as A Partial Replacement for Fine Aggregate in Concrete, Waste Managemenet, 29, 655-659. https://doi.org/10.1016/j.wasman.2008.08.012, 2009.

Kline, J., and Barcelo, L., Cement and $\mathrm{CO}_{2}$, A Victim of Success!, Cement Industry Technical Conference, IEEEIAS/PCA, 53, 1-14, 2012.

Kong, Y., Wang, P., Liu, S., Gao, Z., and Rao, M., Effect of Microwave Curing On the Hydration Properties of Cement-Based Material Containing Glass Powder, Construction and Building Materials, 158, 563-573, https://doi.org/10.1016/j.conbuildmat.2017.10.058, 2018.

Mehta, K. P, and Monteiro, P. J. M., Concrete: Microstructure, Properties, and Materials, McGraw-Hill, New York, 2006.

Mehta, P. K., Reducing The Environmental Impact of Concrete, Concrete International, 23(10), 61-66, 2001.

Meyer, C., The Greening of the Concrete Industry, Keynote Paper at The 2013 World Congress On Advances in Structural Engineering and Mechanics (ASEM13), Jeju, Korea, September 8-12, 2013.

Moya, J. A., Pardo, N., and Mercier, A., Energy Efficiency and $\mathrm{CO}_{2}$ Emissions: Prospective Scenarios for The Cement Industry, JRC Scientific and Technical Report, 2010.

Ngene, B. U., Olofinnade, O. M., and Agomo, C. E., Effect of Magnetized Water On the Mechanical Properties of Concrete Containing Recycled Waste Glass Aggregate, International Journal of Engineering Research in Africa, 41, 103-114, February, 2019. 
Olofinnade, O., Ede, A., Ndambuki, J., and Opeyemi, A., Sustainable Reuse of Glass and Clay Brick Wastes as Substitute for Natural Aggregate for Production of Green Concrete, $10^{\text {th }}$ International Structural Engineering and Construction Conference, ISEC10, Chicago, USA, May 20-25, 2019.

Olofinnade, O. M., Ede, A. N., and Booth, C. A., Sustainability of Waste Glass Powder and Clay Brick Powder as Cement Substitute in Green Concrete, Handbook of Environmental Materials Management, Springer, 2018a.

Olofinnade, O. M., Ede, A. N., and Ndambuki, J. M., Sustainable Green Environment Through Utilization of Waste Soda-Lime Glass for Production of Concrete, Journal of Materials and Environmental Sciences, 8(4), 139-1152, 2017a.

Olofinnade, O. M., Ede, A. N., Ndambuki, J. M, and Bamigboye, G. O., Structural Properties of Concrete Containing Ground Waste Clay Brick Powder as Partial Substitute for Cement, Material Science Forum, 866, 63-67, 2016.

Olofinnade, O. M., Ede, A. N., Ndambuki, J. M., Ngene, B. U., Akinwumi, I. I., and Ofuyatan, O., Strength and Microstructure of Eco-Concrete Produced Using Waste Glass as Partial and Complete Replacement for Sand, Cogent Engineering, 5, 1483860, 1-19, $2018 \mathrm{~b}$.

Olofinnade, O. M., Ndambuki, J. M., Ede, A. N and Booth, C., Application of Waste Glass Powder as A Partial Cement Substitute Towards More Sustainable Concrete Production, International Journal of Engineering Research in Africa, 31, 77-93, July, 2017b.

Provis, J. L., van Deventer, J. S., Alkali Activated Materials, Springer, 2014.

Schneider, M., Romer, M., Tschudin, M., and Bolio, H., Sustainable Cement Production -Present and Future, Cement and Concrete Research, 43, 642-650, 2011.

Shakir, A. A., Naganathan, S., and Mustapha, K. N., Effect of Quarry Dust and Billet Scale Additions On the Properties of Fly Ash Bricks, Iranian Journal of Science and Technology, Transactions of Civil Enginnering, 38(C1), 51-60, 2014.

Shao, Y., Lefort, T., Moras, S., and Rodriguez, D., Studies On Concrete Containing Ground Waste Glass, Cement and. Concrete. Research, 30, 91-100, https://doi.org/10.1016/S0008-8846(99)00213-6, 2000.

Shayan, A., and Xu, A., Value-Added Utilisation of Waste Glass in Concrete, Cement and. Concrete. Research, 34, 81-89, https://doi.org/10.1016/S0008-8846(03)00251-5, 2004.

Tan, K. H., and Du, H., Use of Waste Glass as Sand in Mortar: Part 1 - Fresh, Mechanical and Durability Properties, Cement and Concrete Composites, 35, 109-117, 2013. 